\title{
A Review of Accountability Audit
}

\author{
Liang Li \\ School of Management, Jinan University, Guangzhou, China \\ Email: liliang646@163.com
}

How to cite this paper: Li, L. (2019) A Review of Accountability Audit. American Journal of Industrial and Business Management, 9, 439-447.

https://doi.org/10.4236/ajibm.2019.93029

Received: February 18, 2019

Accepted: March 11, 2019

Published: March 14, 2019

Copyright (c) 2019 by author(s) and Scientific Research Publishing Inc. This work is licensed under the Creative Commons Attribution International License (CC BY 4.0).

http://creativecommons.org/licenses/by/4.0/

\begin{abstract}
In the report of the Third Plenary Session of the 18th Central Committee, it was clearly stated that the implementation of the accountability audit, speeding up the construction of ecological civilization, strengthening the responsibility for environmental protection, and establishing an accountability system for environmental protection. The accountability audit is a new extension of government audit in the function of state governance, which plays an important institutional role in regional environmental governance and has a deterrent effect on government officials in various regions. The main purpose of this paper is to review the theoretical basis of the accountability audit, to explore the mechanism principle of the accountability audit and the analysis of the accountability audit by the analysts. The conclusion is that the accountability audit is a new development of the national audit function, and providing a supervisory role in natural resources and the natural environment.
\end{abstract}

\section{Keywords}

Accountability Audit, Government Audit, Regional Environmental Governance

\section{Introduction}

Accountability Audit is a new extension of the role of government audit in national governance. Government audit is the cornerstone and important guarantee of state governance, serving the modernization of the national governance system and governance capacity [1]. Government audit has a special status and plays an important role: on the one hand, as an important part of the state power system, it can play an effective check and balance mechanism; on the other hand, by exerting the functions of "immune system" such as prevention, revealing and resisting, government audit improves the efficiency of state power operation and gradually becomes the basic system for the central government to motivate and control local governments [2]. 
In recent years, large-scale vicious environmental production accidents, environmental pollution, resource shortages and ecological deterioration have occurred throughout China, seriously affecting people's quality of life, and the contradiction between economic development, social security and environmental protection has become more prominent, leading to environmental groups. In the new era, China began to turn to high-quality development, and accelerating the construction of ecological civilization has become an important task of national governance. Traditional government audits are constantly evolving under the new governance requirements. The implementation of accountability audit and the establishment of an environmental responsibility accountability system are the systems to enhance local government environmental protection awareness, strengthen environmental protection responsibility, and promote ecological civilization construction. In 2013, the "Decision of the Central Committee of the Communist Party of China on Comprehensively Deepening the Reform of Some Major Issues" (hereinafter referred to as the "Decision") adopted by the Third Plenary Session of the 18th CPC Central Committee clearly stated that the leading cadres should be audited for the departure of natural resources assets and establish an ecological environment. In 2014, Inner Mongolia, Fujian, Guizhou, Shandong and other provinces took the lead in conducting pilot projects for the departure audit of natural resource assets, and actively explored the governance effects brought about by natural resource departure audits.

\section{Literature Review}

\subsection{Government Audit}

Government audit is the product of political civilization, and its connotation is constantly evolving. Domestic and foreign scholars have different views on the meaning of government auditing. The chief auditor of the US Audit Office, Elmer B. Steaz, proposed in 1976 that the primary purpose of government audit was to promote the economics and efficiency of work at all levels of government. Zhang Qinglong pointed out that government audit is the authenticity and fairness of the financial audit reports of the state and local government departments and other public institutions, the economics, efficiency and effectiveness of the use of public resources, and the quality of providing public services [3]. Conduct an audit. Chen Yuan and Song Xiayun have a deeper understanding of the content of government audit [4]. They believe that the basis of government audit lies in public fiduciary responsibility and will expand as the content of fiduciary responsibility changes.

In summary, the connotation of government audit is mainly reflected in the following three aspects: First, the main body of government audit is the government audit organ, and the target of government audit is the heads of government agencies at all levels and relevant departments. Second, like other types of audits, government audit arises with the creation of public fiduciary responsibilities, which is essentially an institutional arrangement that ensures that public 
fiduciary duties are fulfilled. Government agencies as public trustees accept the entrustment of the people, the government must engage in economic management and reporting behaviors according to specific requirements or principles, and effectively fulfill relevant responsibilities [5], the use and management of social public resources Responsible for compliance, fairness, efficiency, economy and effectiveness. Third, with the development of the times and the changes in the social and economic environment, the content of public fiduciary responsibility is also deepening, so the function of government auditing should be continuously expanded. Liu Jiayi put forward the "immune system" function of the government audit. He believes that government audit is essentially an "immune system" with the functions of preventing, revealing and resisting. It has the conditions and the responsibility to timely discover the problems that endanger the national economic security and the democratic rule of law.

Regarding the development of government audit in China, it has mainly gone through three stages. The early government audit focused on financial and financial revenue and expenditure audits. The main purpose was to explain the problems in the implementation of the budget process by state organs, institutions, state-owned enterprises and state-owned financial institutions. Wei Dehong et al. studied government audit effectiveness and finance [6]. In the security relationship between funds operation, it is found that the improvement of government audit effectiveness helps to improve the security of financial funds. Later, with the deepening of the national economic system reform and the development of political system reform, the government audit as a national monitoring tool will be tentacles. In-depth to economic responsibility auditing and fraud auditing, the purpose is to further evaluate the performance of leaders participating in economic activities through auditing, and extend the confirmation of whether there are corruption and other violations in the performance stage [7]. In the 21 st century, the effectiveness audit with Chinese characteristics quickly covers the scope of performance audit with "economics, efficiency, and effectiveness" as the core, with "authenticity, legitimacy, economy, efficiency, effectiveness and environment". Economic development is usually accompanied by environmental pollution. To ensure sustainable development, environmental protection needs to be carried out while developing the economy [8].

The research on the state governance function of government audit can be elaborated from two aspects: extensive governance function and specific functional performance. First of all, government audit is the cornerstone of government governance and an important guarantee for the modernization of state governance. As a key part of the government governance system, government audit has two broad functions. The first is to verify and evaluate the activities of government departments, expose violations, and provide independent and objective opinions and evidence for the public to understand the use of public resources by government departments. The second is to indirectly deter and supervise through the effective implementation of audit work. Government departments give full play to their functions and improve the effectiveness of gov- 
ernment governance [9]. Second, the specific functions of government audit can be reflected in the following aspects: First, to ensure national economic security. Zhang Qinglong and Xie Zhihua analyzed the relationship between government auditing and national economic security from the perspectives of auditing essence, government supervision and institutional equilibrium. They also studied the role of government audit in the protection of national economic security and the role of strategic defense and micro-system clearance and repair. The study also shows that government audit plays a role of supervision, early warning and service in the formulation and implementation of national macroeconomic policies, the operation of national key industries, national financial security, and national sustainable development [10]. The second is to improve government transparency. A large amount of literature studies the relationship between corporate auditing and corporate information transparency. The company's audit can form a supervisory and deterrent effect on listed companies, improve the company's information transparency, and protect stakeholders to a certain extent [11], and there are relatively few studies on government audit and government transparency. Auditing independent auditing of government information can ensure the authenticity of government information disclosure. Zhu Rong uses China's provincial level data to empirically test Government audits have played a positive governance role in improving government transparency [12]. The third is to curb corruption. The main targets of government audits are fiscal and fiscal revenues and expenditures, covering almost all government agencies' finances. Therefore, government audits have unique advantages such as professionalism and regularity in discovering and punishing corruption [13] [14] [15]. The government audit's corruption governance function is also manifested in its ability to prevent corruption from its roots. While the auditing agency reveals the problems of the audited entity, it also analyzes the root causes of the problem and improves the system to prevent the occurrence of corruption [16]. The fourth is to implement performance audits to improve the efficiency of state-owned enterprises. Government auditing is an important duty of state-owned enterprises [17] [18]. Cai Li et al. took the listed companies of central enterprises from 2008 to 2012 as the research object, and took the company's operating performance as the research entry point [19]. The research results show that the government audit has positively promoted the improvement of the operating performance of the listed companies in the central enterprises.

\subsection{Accountability Audit}

With the continuous development of society and the continuous improvement of the national system, the scope of government auditing is also expanding according to the new development needs. The departure audit of the natural environment and natural assets is a new aspect of government auditing in the function of state governance. Claim. Before 2014, China did not have specific regulations on the accountability audit. Only part of the literature believed that resource and environmental audits should be included in the economic assessment 
of officials. From the Third Plenary Session of the 18th CPC Central Committee, "Leading Cadres Naturally after the Audit of Resource Assets Leaving the Company", the domestic research has been carried out successively and formed a certain theoretical basis.

Chinese scholar Cao Shujing earlier proposed that the departure audit of leading cadres should combine economic responsibility and environmental responsibility [20]. It is considered that the environmental audit is included in the scope of the "sustainable development" strategy, and the environmental audit is explained the main content, as well as the application of leaving the environmental audit. Huang Rongbing believes that the concept of green economy puts forward new requirements for the evaluation of party and government leading cadres, and should incorporate environmental protection responsibility into the evaluation scope of economic responsibility audit [21]. In addition, Bi Jun believes that to break the local GDP development theory, the performance evaluation of leading cadres should be changed from traditional economic GDP to green GDP [22]. In the past, scholars have conducted more theoretical research on the departure of natural resource assets. Liu Changcui et al. pointed out that the political environment is an important factor in the development of resource and environmental auditing [23]. If the resources and environmental responsibilities of party and government leading cadres are not emphasized, the audit of resources and environmental responsibility is difficult to carry out in depth. Zhang Ting proposed that the government accepts the commission of the public to manage natural resources, while the leading cadres, as managers of the government, must bear the primary responsibility for the development, utilization and protection of natural resources, and it is necessary to be responsible for the natural resources assets [24]. The implementation of the situation is properly monitored. Cai Chun and Bi Mingyue conducted research on social motivation, laws and regulations, motivation, business reflection theory, and entrusted economic responsibility theory [25]. They believe that natural resources belong to the common property of the public, and the government manages and uses natural resources through entrusted methods. The government's protection of natural resource assets when emphasizing performance did not meet the expectations of the public, making the public a victim of environmental pollution. Therefore, the audit of natural resource assets that reflects the needs of the public has been generated.

Scholars also discussed some of the auditing elements of accountability audit. Cai Chun and Bi Mingyue, Liu Minghui and Sun Yuping respectively expounded the concept of the departure audit of natural resource assets of leading cadres, and considered that accountability audit is "the auditing agency obtains and evaluates audits according to relevant laws, regulations and other standards. Evidence, supervising, evaluating and verifying the performance of the responsibility of natural resources asset management and ecological environmental protection for the main leading cadres of the party and government, and communicating the audit results to the systematic process of the intended users" [25] [26]. 
Liu Minghui and Sun Yuping believe that the auditing body is an auditing body, including the auditing agency and its dispatched agencies and local auditing organs, while Chen Xiandong believes that the auditing body is not only a national auditing agency [27], but also an internal auditing agency, an intermediary institution and the public because They play different roles in the departure audit. In the "Pilot Program for Conducting the Departure Audit of Natural Resources Assets of Leading Cadres", the audit object was clearly written as the party committee of the local level and the main leading cadres of the government. There are four views on the audit objectives of leading cadres' natural resource assets: responsibility concept (Lin Zhonghua [28]), national governance concept (Li Sheng and Yang Ligao [29]), resource management concept (Qian Shuixiang [30]) and property rights protection View (Chen Bo [31]).

In addition, there are also literatures that summarize the trials of accountability audit. Chen Chaobao et al. found that Jiaozhou City, Shandong Province, achieved good results after auditing the departure of natural resources assets [32]. Through auditing, it discovered and solved some hidden risks in the field of natural resource asset management, strengthened the awareness of ecological civilization of leading cadres, and promoted norms, the management of natural resource assets. Wang Zhenduo and Zhang Minxin combined the pilot practice of the natural resources asset departure audit of leading cadres in Inner Mongolia Autonomous Region, and conducted research on the performance of leading cadres before and after the resignation audit, and found the basic situation of grassland resource assets [33], ecological changes in layoffs, grass and livestock The implementation of the balance system, the basic grassland delineation, grassland protection and supervision and inspection indicators have all improved after the natural resource assets are resigned. Accountability audit will also have certain deficiencies in the actual pilot work. Yang Jianrong et al. based on the departure audit of water resources in A city, found that the data on the preparation of water resources balance sheet is not comprehensive, it is difficult to reflect changes in water resources capacity, water environment capacity and water quality, and lack of protection of water resources and other natural Issues such as coordination of resource asset protection [34].

\section{Comment on the Review}

From the above literature review, it can be seen that the focus of government audit is on the function of economic supervision, and it rarely involves environmental auditing. With the development of society, the public's demand for the natural environment of "green mountains and green mountains" is increasing. Accountability audit as a new development of government auditing echoes the needs of society to a certain extent. The research on accountability audit is still a relatively new topic. Accountability audit is focusing on the protection of the ecological environment and forming a certain binding force on the governance of the regional environment. 
Regarding the future research ideas, the previous literature mainly focuses on the theoretical research of the accountability audit. Therefore, in the future, it is possible to conduct more empirical research on whether the environmental quality of the cities that have passed the pilot audit has been improved. In the future, it is also possible to study the extent to which the accountability audit affects officials with different traits.

\section{Conflicts of Interest}

The author declares no conflicts of interest regarding the publication of this paper.

\section{References}

[1] Liu, J.Y. (2015) State Audit in the Process of National Governance Modernization: Institutional Guarantee and Practice Logic. China Social Sciences, No. 9, 64-83.

[2] Liu, J.Y. (2012) On State Governance and State Auditing. China Social Sciences, No. 6, 60-72.

[3] Zhang, Q.L. and Xie, Z.H. (2009) On Government Audit and National Economic Security. Audit Research, No. 4, 12-16.

[4] Song, X.Y. (2006) Research on National Auditing Objectives and Implementation Mechanism. Shanghai University of Finance and Economics, Shanghai.

[5] Cai, C. and Cai, L. (2012) New Development of National Audit Theory Research-Based on the Perspective of National Governance. Audit and Economic Research, 27, 3-10+19.

[6] Wei, D.H., Qi, Z.Y. and Tang, S.Q. (2010) Research on the Relationship between Government Audit Effectiveness and Financial Operation Security-Based on Statistical and Empirical Research of Audit Yearbook Data. Audit Research, No. 3, 9-14.

[7] Shi, X., Li, S.H. and Xu, Y. (2009) Research on the Nature, Function and Government Audit Responsibility of Audit-Based on the Perspective of the Function of "Immune System". Audit and Economic Research, 24, 8-13.

[8] Wang, S.M., Li, Z.D. and Chen, Y.J. (2009) On Government Audit and National Economic Security. Journal of Zhongnan University of Economics and Law, 172, 95-99.

[9] Zheng, S.Q. (2015) The Basic Theory Exploration of Government Auditing: Based on the Perspective of Public Governance. China Speech Press, Beijing.

[10] Cai, C. and Li, J.T. (2009) Research on Auditing of Economic Power Audit-A New Field of Audit Theory Research. Audit and Economic Research, 24, 3-8.

[11] Wang, P. and Zhou, L.A. (2006) Control, Ownership and Company Performance of Controlling Shareholders: Evidence Based on Chinese Listed Companies. Financial Research, No. 2, 88-98.

[12] Zhu, R. (2014) An Empirical Study of National Auditing to Improve Government Transparency: Empirical Evidence from Provincial Panel Data. Audit and Economic Research, 29, 23-30.

[13] Li, M.H. and Liu X.X. (2013) The Role of Government Audit in State Governance. Political Science Research, No. 3, 35-50.

[14] Liu, J. and Lin B. (2012) Government Auditing and Corruption Control: Evidence 
from China's Provincial Panel Data. China Journal of Accounting Research, 5, 163-186. https://doi.org/10.1016/j.cjar.2012.01.002

[15] Ferraz, C. and Finan, F. (2011) Electoral Accountability and Corruption: Evidence from the Audits of Local Governments. American Economic Review, 101, 1274-1311. https://doi.org/10.1257/aer.101.4.1274

[16] Li, J.T., Miao, L.Q. and Liang, Y.H. (2011) Empirical Study on the Operational Effect of Economic Responsibility Audit. Audit Research, No. 3, 24-30.

[17] Qin, R.S. (2004) The Theory of Public Responsibility for Economic Responsibility and the Audit Reform of Chinese Government. Audit Research, No. 6, 16-20.

[18] Ge, X.T. (2005) A Probe into the Government Audit Reform in the Transformation of Government Functions. Audit Research, No. 1, 75-78.

[19] Cai, L. and Ma, K.N.N. (2014) Government Auditing and Governance Efficiency of State-Owned Enterprises-Based on Empirical Evidence of Central Enterprises Holding Listed Companies. Audit Research, No. 6, 48-56.

[20] Cao, S.J. (1999) The Cadre Should Be Responsible for the Audit of Land Resources Protection Responsibility. China Land, No. 4, 17-19.

[21] Huang, R.B., Shan, J.N. and Shi, X.X. (2010) Economic Responsibility Audit of Party and Government Leading Cadres from the Perspective of Green Economy. Audit Research, No. 4, 33-36.

[22] Bi, J. (2013) Ecological Civilization Is the Cornerstone of Modernization in Southern Jiangsu. Xinhua Daily, 2013-08-20 (B07).

[23] Liu, C.C, Zhang, H.L. and Huang, W.S. (2014) Environment of Resource Environment Auditing: Structure, Impact and Optimization. Audit Research, No. 3, 38-42.

[24] Zhang, T. (2015) Review and Reform Suggestions on the Status Quo of Natural Resources Assets Departure Audit in China. Business Accounting, No. 24, 32-34.

[25] Cai, C. and Bi, M.Y. (2014) Theoretical Thinking on the Departure Audit of Natural Resources Assets. Audit Research, No. 5, 3-9.

[26] Liu, M.H. and Sun, Y.P. (2016) Research on the Auditing Factors of the Retirement of Natural Resources Assets of Leading Cadres. Audit and Economic Research, 31, 12-20.

[27] Chen, X.D. (2014) Some Thoughts on Conducting the Audit of the Departure of Natural Resources Assets of Leading Cadres. Audit Research, No. 5, 15-19.

[28] Lin, Z.H. (2014) Discussion on the Audit of the Departure of Natural Resources Assets of Leading Cadres. Audit Research, No. 5, 10-14.

[29] Li, S. and Yang, L.G. (2016) Research on the Departure Audit of Natural Resources Assets Based on the Perspective of National Governance Modernization. Journal of Finance and Economics, 37, 85-89.

[30] Qian, S.X. (2016) Research on the Audit of the Departure of Natural Resources Assets of Leading Cadres. Zhejiang Social Sciences, No. 3, 151-155.

[31] Chen, B. (2015) On the Retirement of Natural Resources Assets Based on Property Rights Protection. Audit and Economic Research, No. 5, 15-23.

[32] Chen, C.B., Yan, X.Y. and Meng, C. (2016) Practice and Thinking of the Resignation of Natural Resources Assets of Leading Cadres in Jiaozhou City. Audit Research, No. 4, 10-14.

[33] Wang, Z.D. and Zhang, M.X. (2017) Research on the Auditing Content of the Retirement of Leading Cadres' Grassland Resources Assets-Based on the Audit Practice of Inner Mongolia Autonomous Region. Audit Research, No. 2, 31-39. 
[34] Yang, J.R. and Gao, Z.P. (2017) Research on the Path of Auditing the Retirement of Natural Resources Assets of Leading Cadres-Taking Water Resources in City A as an Example. Audit Research, No. 1, 23-28. 